\title{
Heimat as a Geography of Postwar Renewal: Life after Death and Local Democratic Identities in Cologne, 1945-1965*
}

Jeremy DeWaal

\section{Introduction}

In 1947 the archivist of the south-western city of Constance noted an unprecedented turn to the concept of Heimat, the German term for local and regional places of home. Heimat values, he argued, 'are today, amidst the collapse of so many other basic principles, more valuable than they ever were in peaceful times'. ${ }^{1}$ Others in the region made similar statements and discussed how Heimat offered new opportunities for postwar lives as well as values including 'SwabianAlemannic democracy', 'Swabian openness to the world' ( Weltoffenheit), 'Baden 'democracy' and 'Baden openness to the world'. ${ }^{2}$ This pattern was hardly unique to the south-west. Seven hundred kilometres to the north, in the Hanseatic cities, local citizens, authors and officials noted that 'glowing love' of Heimat reached greater heights in the ruins than in times of the city's 'blossoming'. ${ }^{3}$ Localists of the Hanseatic cities discussed their hometowns as representing their 'desire to live' and wrote of how Hanseatic 'democracy' and 'openness to the world' would shape a new era. ${ }^{4}$ Turning to another region, we find a remarkably similar pattern in the Rhenish city of Cologne, the subject of this study. Accounts from the city of rubble contain prolific expression of both loss of and desire for Heimat. Citizens of Cologne in ruins spearheaded an astonishing renaissance of local Heimat culture, founded a profusion of Heimat societies and publications, wrote a flood of dialect songs and poetry, held frequent Heimat evenings, planned major localist events and revived local traditions. In 1947 a city report noted the popular 'wildgrowing Heimat cultural activities' that thrived in the ruins. ${ }^{5}$ Citizens not only discussed Heimat as a site of life affirmation (Lebensbejahung), but also argued for the value of Cologne democracy, openness to the world and tolerance in a new postwar order. 
This article argues that a popular emotional geographic turn occurred in the ruins of postwar cities and regions, away from notions of the nation as a redemptive force and towards local and regional places as geographies of renewal that offered spaces of life after death and sources of early democratic and European identification. This by no means entailed an abandonment of national sentiment, with the Heimat idea offering a medium for imagining a federalist nation. Many argued that a joint focus on local Heimat and European unity would moderate and thereby improve, but not displace, the national idea. This study traces these developments by examining discourses in postwar Cologne in a wide range of media, including local newspapers, Heimat journals, reports and programmes from events, dialect songs and poetry, speeches, reports from the city administration, private accounts and early postwar monographs on local history and culture.

Despite the prevalence of references in such sources to Heimat reaching unprecedented height in the ruins, historians have often overlooked this popular turn and its impact on postwar culture, politics and identifications. Studies by Celia Applegate on the Palatinate and Jörg Arnold on the memory of the bombing of German cities have offered important insights into early postwar attraction to the concept, while Jan Palmowski's work on the German Democratic Republic has shown how the regime used it to foster identification with the new state. ${ }^{6}$ At the same time, the stubborn myth of Heimat after 1945 as a taboo term has remains present. ${ }^{7}$ Moreover, regional studies that do recognize the appeal of Heimat in the West often dismiss it as defined by ruralism, anti-Westernism, repression of the past, regressive forms of environmental protection or self-victimization. ${ }^{8}$ In a related vein, Alon Confino, viewing Heimat as an empty signifier of national self-depiction, looks to early postwar tourism to argue that Heimat after 1945 was primarily about repressing the past and emphasizing national victimhood. ${ }^{9}$ 
The thesis of postwar ideas of Heimat as primarily defined by regressive political agendas has also figured prominently in works on Heimat film, which represent Heimat as a generic rural space. While Johannes von Moltke offers a convincing alternative interpretation of these films as negotiating the terms of modernity, what is still lacking is consideration of Heimat as actual places of home, lost and reimagined. ${ }^{10}$ Far from being generic stretches of countryside, specific places of Heimat were sites of personal memories, community, social networks, history and local identity that had been shattered by war. Looking beyond ruralist tropes in film and tourism, we must examine how the loss of actual sites of Heimat, the desire for their reacquisition and the flexibility of local and regional identities shaped early postwar histories of cultural life, democratization and the search for sources of renewal.

Popular use of Heimat to promote identification with democracy conflicts with persisting notions of Heimat as inherently regressive. ${ }^{11}$ It also raises questions about portrayals of early West German democracy as concealing a non-committal or hostile population. ${ }^{12}$ Historians have shown how the 'economic miracle' and liberalization of the 1960s increased support for democracy, though more attention is needed to earlier popular attempts to forge new identifications in the immediate postwar years. ${ }^{13}$ This requires an expansion of the discussion beyond elites and yardsticks of democratic practice to encompass lay discussions of democracy. Vague local identifications did not suddenly transform citizens into adept practitioners of democracy, and the 'search for democracy as a way of life' remained a long process. ${ }^{14}$ At the same time, they represented a crucial first step upon which subsequent processes built.

While the turn to Heimat can be traced in areas both urban and rural, Cologne offers an example from one of the most ravaged landscapes in postwar Germany. Though the Third Reich appealed to local allegiances in propaganda, the war ended with the Heimat's complete 
devastation, with the city $90 \%$ destroyed and all but 40,000 of 770,000 inhabitants evacuating. The nation had ceased to exist as a sovereign political actor, with returnees to Cologne instead describing their locality as containing the seeds of new life. Such notions of Heimat as a site of new life derived in no small part from its role in bridging ruptured biographies and offering a countervailing force of communal cohesion. To forge local cohesion for reconstruction, localists particularly emphasized unity across divisions of confession and political party, while avoiding extensive confrontation with the divisive issue of guilt for the Nazi past. This turn away from national struggle and toward local Heimat as a site of imagining new lives, I argue, ultimately redound to the benefit of federalism and cultural demobilization. ${ }^{15}$

Use of local Heimat to reshape identities in Cologne could be seen immediately after 1945 with the emergence of the new metaphor of Cologne as a 'bridge' to the West that was infused with 'Cologne openness to the world'. Locals fashioned these notions by harkening to key local historical memories and used such local identity claims to advocate for European unification. These years similarly saw articulation of 'Cologne democracy' as a local value, while many Cologne Heimat enthusiasts argued that local orientations were essential to democracy, federalism and political participation. Meanwhile, ideas of 'Cologne tolerance' increasingly came to the fore by the 1950 s, which many locals used to counter discrimination against expellees and later immigrants. Such new identifications hardly did away with many underlying mindsets and practices, while aggravating failures to confront local guilt for the Nazi past. At the same time, they provided useful tools for disbanding the dangerous notion that democracy and European unity were foreign entities.

\section{From Nazi Co-ordination to Defeat}


In 1945 citizens of war-torn Cologne confronted a landscape of ruins unparalleled in German history. While the extent of the destruction was unprecedented, cultural and political renegotiation between local and national worlds in the aftermath of war was hardly new. Generations earlier the Napoleonic wars had churned up a mixture of nascent nationalism, regional state-building and localist sentiment, while the wars of German unification had seen both a transfer of political sovereignty to the nation and a cultural turn to localities and regions. ${ }^{16}$ The aftermath of the First World War offers perhaps the most interesting contrast, witnessing both a growth in separatism and in Heimat publications and a contrasting turn to redemptive nationalism. As Peter Fritzsche argues, after 1918 'the most authoritative means by which individuals made sense of their losses was by identifying their own fate with that of the nation'a development that contributed to the rise of National Socialism in Germany. ${ }^{17}$

Though the role of Heimat in the Third Reich remains a matter of debate, Nazi ideology lacked a clear orthodoxy regarding the concept, displaying divergent and ambivalent attitudes. ${ }^{18}$ While Adolf Hitler declared that the regime would eliminate federalism and praised the ways in which technologies of movement would level regional difference, the Third Reich was hardly the most centralized dictatorship. ${ }^{19}$ Gauleiter in particular took advantage of regional identity politics, while a number of Heimat enthusiasts proved ideologically receptive. ${ }^{20}$ At the same time, the regime curtailed Heimatkunde (local studies) and the publication of Heimat books and between 1933 and 1940 slashed the number of Heimat journals by 40 per cent (see Fig. 1). ${ }^{21}$ As one Nazi pedagogue argued, only history rooted in spaces of 'national destiny' should be taught. Historical views based on Heimat, he argued, were products of a 'liberal' world-view that should be scrapped. ${ }^{22}$ In the Rhineland, ideologically receptive Heimat societies like the Rheinischer Verein für Denkmalpflege were easily integrated, while others, like the Heimatverein Alt-Köln, 
were forbidden to publish. In 1934 the youth Heimat publication Jung-Köln, edited by the Cologne school board, also came to an end. ${ }^{23}$

The regime used Heimat in propaganda, and Heimat enthusiasm never emerged as a site of resistance. Co-ordination of Cologne Carnival, for example, saw only brief conflict over local societies' independence followed by accommodation between the regime and organizers. Carnival functioned as a moderately effective venue for propaganda with only isolated resistance. ${ }^{24}$ Co-ordination of journals like the Rheinische Heimatblätter offers insight into the regime's ambivalent approach to Heimat. After 1933 the formerly apolitical journal was removed from editorship of Heimat societies and renamed the Rheinische Blätter, with regional pieces dramatically scaled back to make way for non-regional propaganda. Remaining regional sections took on new themes, including the Rhineland's 'war-front legacy', the artificial western national border, regional economic output and denunciations of separatism. ${ }^{25}$ In drawing on local histories, including ideas of Cologne as a Hanseatic city, the regime largely sought to force the inward focus of Heimat outward. As the new Nazi mayor argued in the journal in 1933, it was a Rhenish duty to emphasize 'German cultural will' to such a degree that it would 'radiate' across the western border. ${ }^{26}$

During the war years connection to Heimat had been challenged by destruction, death and dislocation. Soldiers' homesickness also represented a problem for military strategists, while plans to resettle millions of Germans to the East illustrated a lack of concern with maintaining citizens' local rootedness. At the same time Nazi propaganda did not hesitate to appeal to local loyalties, as Malthe Thießen illustrates for Hamburg. ${ }^{27}$ In the Rhineland such appeals grew during the war years, with a focus on mobilizing local resources. As the Westdeutscher Beobachter declared in 1940, 'Heimat and front are one. ${ }^{\text {,2 }}$ The subsequent bombings made that 
claim a critical reality. Propaganda decried the British 'terror attacks' and cultural 'barbarism' and underscored the need to strike against the British 'mass murderers'. The destruction of Cologne's famous Romanesque churches provided one tool for appeal to local sentiment. ${ }^{29}$ Attempts to use the destruction of their Heimat to strengthen local resolve had mixed results, as two private letters from 1943 illustrate. While one woman from Cologne wrote in a letter that saying Heil Hitler after the bombings would likely get one slapped, a father wrote to his son in the field of how seeing in the ruins the statue of the 'Kölsche Boor'(a representation of the Citizen of the Free Imperial City of Cologne) had filled him with a desire for vengeance. ${ }^{30}$ Appeal to local sentiment increased in 1944 as the Allies approached the border, with propaganda praising the 'true Heimat loyalties' of those who sacrificed their lives for the nation, while denouncing the 'false Heimat loyalties' of locals who refused to be evacuated. ${ }^{31}$ At moments of crisis during the war, as Nicholas Stargardt points out, the regime sought to rekindle hope for victory, and many Germans viewed the war through the lens of hope for postwar life. ${ }^{32}$ In turn, propaganda towards the end of the war emphasized not only hope in final victory but also that there would be no civilian life of Heimat after defeat. As the Westdeutscher Beobachter maintained the Allies would decimate the city, drive out its inhabitants, give the Rhineland to France and enslave Rhinelanders far from their Heimat. ${ }^{33}$

The idea of the national Volksgemeinschaft (people's community), though certainly having local manifestations, ultimately outshone that of Heimat as a focal point in Nazi ideology. ${ }^{34}$ Scholars continue to debate whether the final war years saw a decline in the appeal of the Volksgemeinschaft idea and whether the idea left imprints on postwar memory cultures or on notions of a 'community of fate' ${ }^{35}$ After 1945 , however, one thing was clear: the nation had been eliminated as a sovereign actor and the Volksgemeinschaft was no longer a viable source of 
deliverance. The immediate postwar years, moreover, hardly seemed a prelude to better times, as citizens faced widespread destruction, dislocation, fragmented communities, ruptured biographies, vulnerability and a highly uncertain national and political future. Heimat offered an imagined source of renewal in confronting many of these challenges, representing a site of new life, potential community solidarity, repaired personal biographies, flexible political identities and federalist national ideas. From the perspective of early postwar Germans, the Heimat concept was entirely untainted. In examining thousands of sources of early postwar discussions on Heimat from a range of genres, authors and places, we find not only numerous references to Heimat reaching unprecedented heights, we also find virtually no reference to Heimat as tainted or even defence against the notion that it was contaminated.

Loss of Heimat has historically been a powerful impetus for preoccupation with the concept. ${ }^{36}$ Citizens of Cologne wrote prolifically on how lost Heimat resulted in emotional preoccupation with their hometown. As one elderly doctor recorded after witnessing the rubble sites of his former life, he felt a burning desire to see prior to his death not a rebuilt Germany, but the rebuilt city of Cologne. ${ }^{37}$ Popular dialect lyrics reflected on the rubble not in terms of the defeated nation, but as disintegrated personal memories, local friendships and familiar places of home. Rather than declare that Germany must be rebuilt, such lyrics insisted that 'Colonia' could not be allowed to disappear. ${ }^{38}$ Evacuees similarly reported on their overwhelming desire for Heimat, while local legend maintained that somewhere in their makeshift abode every evacuee had a picture of Cologne Cathedral, as a symbol of their desire for return. ${ }^{39}$

As early as 1945 evacuees poured back into the city, with their precipitous arrival discussed in terms of desires for Heimat. In the first eight months, an astonishing 400,000 people returned, often on foot, to a city that had been 90 per cent destroyed. ${ }^{40}$ Many recounted singing 
on their treks not the Deutschlandlied, the German national anthem, but rather the song 'Heimweh nach Köln' (Homesickness for Cologne), with locals widely reporting the popularity of this song in the ruins. ${ }^{41}$ Years before, the Nazis had forbidden Cologne soldiers to sing the song as it implied a desire to abandon the war effort. ${ }^{42}$ When evacuated citizens finally arrived back to find shattered communities and the places of their former lives gone, they often reported heightened feelings of lost Heimat. As one collector of local stories recounted, underneath the rubble existed a buried world of former neighbours and all the elements of a lost personal world. ${ }^{43}$ Another Cologne citizen wrote after wandering between vanished sites of his former life how he felt perplexed that no one was there to greet him and became overwhelmed with the feeling that his 'youth had withered away'. Heimat, he concluded, appeared to be no more. ${ }^{44}$ Local administrators confessed themselves flabbergasted at the irrational behaviour of returnees who would have been materially better off if they had stayed in the countryside. The local press reported, however, that desire for Heimat motivated precipitous return. An article in the first postwar newspaper noted that the people of Cologne were 'loyal to Heimat' and would rather live in basement ruins that in a perfect house outside the city. ${ }^{45}$ In 1946 the Kölnische Rundschau similarly reported that the dominant attitude could be described by the phrase 'No, it must be Cologne!'—a remark made by a determined returnee. ${ }^{46}$ In 1949 the Westdeutsche Zeitung asked rhetorically, 'Are these large cities of our time, in particular the large settlements of rubble, Heimat in a deeper sense to those people who reside within them?' The article continued that the droves of returnees provided a clear answer. ${ }^{47}$ Heinrich Böll, meanwhile, remarked on how Cologners viewed returning to their home city as the 'only opportunity to have hope' ${ }^{49}$ Heimat, in short, was not simply about recounting suffering; it also represented a search for new life. 


\section{Heimat, Reconstruction and Life after Death}

In August 1945 a telling article appeared in the Kölnischer Kurier entitled 'Heimatliche Melodie' that sheds light on the popular attraction to Heimat. The article contained an account of a citizen awakening to the sound of a neighbour cleaning a carpet out of an open window. The writer confessed himself baffled that such an act existed. The sound, he wrote, had not been heard for years and represented for him a 'Heimat-neighbourly household melody' that engendered within him an 'unusual feeling of newly won, no, more, a newly gifted Beheimatung, ${ }^{50}$ That such an article appeared in the meagre four-page weekly newspaper attests to the depth of desire for the personal life of Heimat - a life that would no longer be determined by expansive ideology, destruction and the threat of death.

Historians have posed the question of how postwar citizens sought to pursue new lives after an era of mass death, while examination of local memory cultures has offered some evidence of the locality's importance. ${ }^{51}$ Neil Gregor's study of Nuremberg shows how efforts to bridge local schisms to confront postwar challenges informed generalized narratives of local victimhood ${ }^{52}$ Thießen and Arnold have also demonstrated the importance of localist survival narratives after the bombings of Hamburg, Kassel and Magdeburg, while Arnold further shows how the Heimat concept became crucial in emotional processing of destruction. ${ }^{53}$ Explicit consideration is still needed, however, of how and why local Heimat came to the fore as a site of life after death and what it meant for cultural demobilization-a process which involved eliminating the cultural foundations of war-making. While the Nazi regime had portrayed military victory as the only path to a postwar life of Heimat, amidst the realities of defeat and occupation, the notion of national struggle as a means of achieving new life no longer made 
sense. Discourses in Cologne after the war, in turn, reflected how citizens saw immediate focus on local reconstruction and the return of the everyday life of Heimat, rather than national struggle, as the route to new life.

Crucial to the understanding of Heimat as a space of renewal was its perceived function in repairing personal biographical narratives torn apart by the war. Probing popular discourses in the rubble reveals that many locals saw Heimat as both the primary site where rupture in personal lives registered and the only place where it could be repaired. Citizens' conflation of their fates with the fate of their hometown can be seen in a threefold thematic matrix that suffused localist writings and progressed from: memories of lost personal lives tied to a vanished local stage, the equation of the rubble city with individual plight, and imaginings of a reconstructed city as a source of recovery, reconstruction and 'life affirmation'. This matrix can be found, for example, throughout the torrent of rubble dialect poetry produced in the mid to late 1940s by amateur poets such as Waldemar Cosson, Joachim Henning, Karl Jahn, Jupp Schmitz, Rudolf Roonthal and Albrecht Bodde. Such use of this genre became popular, with the society Alt-Köln reporting in 1948 that members frequently used their events to present dialect poems on the theme of lost Heimat. ${ }^{54}$ In 1945 Bodde wrote not only of a lost former life but also of how Cologne's citizens must reanimate the rubble and maintain local culture to ensure that no one would say, 'Cologne—once upon a time'. ${ }^{55}$ Henning, Jahn and Schmitz's poetry proceeded from memories of a lost world to profess that their hometown, 'Cologne on the Rhine', would remain Heimat and not 'fall asunder'. All would help rebuild 'until our Heimat Cologne is again standing'. As Schmitz wrote, 'when all the sorrow and misery is past' citizens of Cologne would show loyalty through reconstruction. ${ }^{56}$ Dialect poems by Roonthal and Cosson were similarly 
rooted in loss and determination to rebuild, proclaiming a 'vow of fidelity' to Cologne. ${ }^{57}$ 'New life', Cosson argued, would bloom from the ruins and 'Cologne life' would not disappear. ${ }^{59}$

Other local writings from the late 1940s reflected the same progression from loss to local life after death. A volume of rubble sketches from 1946 entitled Colonia Deleta, for example, conveyed Cologne's appearance as a place of 'desert-like absence of Heimat', while arguing that the 'seeds for new life' slumbered beneath the ruins. ${ }^{60}$ The Heimat publication Unser Köln noted in 1948 the breadth of such attitudes, writing of how 'life-affirming desire for the future' grew out of lost Heimat - reflecting a frequent conjoining of the terms Heimat and 'life affirmation' in local discourses. ${ }^{61}$ Such localist energies proved materially useful, with both Heimat enthusiasts and city officials harnessing them for reconstruction through volunteer projects such as Kölle Bliev Kölle.

Recreating Heimat, however, involved more than just physical reconstruction. Though localists lobbied for historic rebuilding, they understood that the lost built environment of Heimat could not simply be restored. Their solution was a robust revival of local culture, which they discussed explicitly as a compensatory space of Heimat, in which revived cultural practices would make up for the lost physical forms of Heimat. Joseph Klersch noted in 1947 that the 'exterior image of Cologne' had been a pillar of 'Heimat sentiment' whose disappearance needed to be compensated for through localist sentiment, to ensure that 'yesterday and tomorrow are not ripped apart in today' ${ }^{62}$ Heimat journals noted that old Cologne could not be physically restored, making preserving local spirit, language, memories and uniqueness all the more important. ${ }^{63}$ This search for a compensatory space of Heimat fuelled a renaissance of local culture, which one city report held resulted from the city's physical loss and from a search for sources of 'new life' ${ }^{64}$ This cultural renaissance saw the emergence of scores of private Heimat societies, which 
generated a wealth of localist publications, mirroring broader West German trends. ${ }^{65}$ Heimat publications issued clear statements of their goals. As the editors of the journal Alt-Köln, closed by the Nazis in 1933, explained in their first postwar edition, their publication was about a 'harkening back' (Rückbesinnung) to local Heimat to gather energies for future challenges. ${ }^{66}$ Viewing the popular revival positively, the city administration created an office of local culture, declaring that the 'wild-growing Heimat cultural activities' should have a centre point that joined their forces together. The administration further argued that maintaining local culture was an 'essential part of spiritual rebuilding'. The office was barred from controlling popular Heimat activities and limited itself to a supportive role. ${ }^{67}$

While locals described Heimat as a site of new beginnings, the localist cultural revival made evident that it was simultaneously about rescuing familiar tradition. The cultural revival took many forms, including the rapid rebuilding of dialect theatres, the explosion of dialect poetry, return of the local Kirmes festival and a string of major localist events. Revival of Cologne Carnival proved particularly prominent, with carnival societies among the first to reemerge, often holding regular 'Cologne evenings' to get through 'grey daily life'. Accounts recorded that locals attended unofficial events in droves, while one carnival song proclaimed that amidst ruins and starvation, locals stood 'shoulder to shoulder' to keep from 'losing themselves' ${ }^{68}$ Several celebrants of carnival described events as displaying a 'bravery to live' and characterized reviving their Heimat tradition as crucial to reconstruction. ${ }^{69}$

Discourses on Heimat and life affirmation continued beyond the late 1940s, while gradually shedding their sense of urgency. By 1949, as rebuilding came into full swing, newspapers cast reconstruction more optimistically as 'Cologne saying yes to life'. ${ }^{70}$ Dialect poetry by locals such as Lis Böhle similarly shifted from earlier pieces that had exigently 
juxtaposed rupture and local life affirmation, to new poems that celebrated reconstruction while bidding adieu to lost places. ${ }^{71}$ In the short term, the economic growth of the 1950 s did not result in the stagnation of the local cultural revival, but instead provided it with greater resources. Makeshift Heimat evenings, temporarily housed dialect theatres and self-published Heimat works gradually gave way to more established forms and elaborate observances. Citizens of Cologne reflected on this in a 1961 carnival float entitled 'tradition's miracle child' which placed the emaciated celebrant of 1945, drowning in his cap, alongside the voluptuous 'well-developed' celebrant of the economic wonder. ${ }^{72}$ By the late 1950 s and the 1960 s, ideas of local life affirmation came to appear in triumphal narratives of reconstruction. ${ }^{73}$ As one local enthusiast maintained, Cologne citizens had demonstrated a 'love of Heimat' and 'life-affirming optimism' that fostered community feeling and fuelled reconstruction. ${ }^{74}$ Konrad Adenauer described Cologne's citizens as having demonstrated a 'will to live, bravery and love of Heimat'. He praised the city for maintaining local culture and welcomed a localism that harmonized tradition and 'progressive spirit'. ${ }^{75}$ Such remembrances, however, often made little mention of the profuse sources of division that such earlier appeals to Heimat had sought to bridge.

\section{Community Cohesion and Memory}

The association of Heimat with life affirmation derived in part from the former's role in promoting community cohesion at a time of division and uncertainty. Popular appeal to the Heimat concept as a means of bridging division extended back to the late nineteenth century, and after 1945 Heimat enthusiasm brought together diverse locals, including participants in a range of private societies, non-affiliated Heimat enthusiasts, city officials and members of the mainstream political parties. ${ }^{76}$ The educated middle class proved particularly active, while 
enjoying support from elites and a receptive audience from below. Emphasis on local cohesion, however, meant avoiding issues that could promote fracture, including confessional differences, excessive party divisions and guilt for the Nazi past. Heimat societies, for example, did not ban former Nazis, while locals uncritically welcomed prisoners of war into the forgiving space of Heimat ${ }^{77}$ Locals further emphasized the co-operation of mainstream political parties in the spirit of Heimat. As one locally patriotic reconstruction poster proclaimed, 'Cologne is in crisis', and whether 'black or red', all should help rebuild. ${ }^{78}$

To avoid confessional friction, Heimat enthusiasts generally emphasized Cologne's Christianity rather than its specific Catholicism, which resulted in an ambivalent relationship with the Catholic Church. After the war, two-thirds of Cologne citizens were Catholic, and the city retained its popular associations with Catholicism. ${ }^{79}$ As Thomas Brodie has illustrated, the Catholic Church sought to shore up local confessional identities and supported Catholic evacuees, while often complaining of their insufficient religious interests. ${ }^{80}$ The Catholic Church and Heimat enthusiasts did co-operate in reviving some local traditions with a religious element, but openly clashed on others, with the church opposing the revival of carnival ${ }^{81}$ Local church newspapers illustrated the church's ambivalence about Heimat in emphasizing both its importance on earth, while warning against excess, as the only real Heimat was in the afterlife. This narrative, presented with added thickness to expellees, made little headway in lay Heimat discourses. $^{82}$

The 700th anniversary of the Cologne Cathedral, celebrated in 1948, represented a particularly telling moment, not only because it demonstrated preference for unity over confessional division but also because it reflected how local Heimat displaced ideas of an embattled national community as the primary imagined force of community cohesion. 
Organizers included the city, the Catholic Church, Heimat societies and a range of local institutions. While the church used the event to depict Cologne as a 'loyal daughter of Rome', a church report noted how the message was lost in reception. ${ }^{83}$ The themes of local community and European unity dominated, with a surprising paucity of national fervour. This seemed anything but inevitable given that the 1880 celebration of the structure's completion had been a major nationalist festival. The 1948 anniversary proved quite different. A report in the Rhein-Echo referred to how the citizens of Cologne would 'de-Prussianize' the cathedral and reverse its fashioning as a national symbol; few, the paper reported, wanted national monuments. ${ }^{84}$ The media reported on the dominance of localist and European sentiments at the celebrations, which the people of Cologne saw as a supra-confessional festival of their local family. ${ }^{85}$ Localist writings described the cathedral as a site of memory of personal lives, a symbol of survival in the ruins and the 'bearer of the Heimat concept' for the people of Cologne of all religions. ${ }^{86}$ Local newspapers argued that the anniversary celebrations conveyed 'Cologne local patriotism' and 'love of Heimat', whether one was Catholic, Jewish or Protestant. ${ }^{87}$ Tellingly, a West Berlin paper reported that the event's expression of desire amongst Cologner for local Heimat reflected similar feelings by Berliners for their own city. ${ }^{88}$

The wish to avoid discord and promote community cohesion certainly aggravated avoidance of divisive confrontation with local guilt for the Nazi past-a phenomenon that Gregor well illustrates for Nuremberg. ${ }^{89}$ Woefully inadequate memorials in Cologne lumped all sufferers into a common category and anonymized perpetrators. Meanwhile, early postwar Jewish life in the city, as Jürgen Zieher has argued, was marked by a mixture of declarations of reconciliation and ongoing antisemitism. ${ }^{90}$ This tension could be found, for example, in the gestures of reconciliation made at the opening of the Cologne synagogue in 1959 which were 
followed by vandalism of the building. Only minor efforts were made in Heimat journals and at the 1,900 th anniversary of the city to reflect on Cologne's Jewish history and antisemitism. ${ }^{91}$ Amidst selfish preoccupation with their own loss of Heimat, locals generally ignored the suffering of Cologne's Jewish community, the survivors of which expressed tremendous feelings of lost Heimat. ${ }^{92}$ Wilhelm Unger, a Jewish citizens who returned, wrote about the anguish of having lost former lives and about wrenching feelings of lost Heimat. He further recalled having sung 'Heimweh nach Köln' with Jews from the city in a refugee camp. ${ }^{93}$ Only a small number of Jews returned to Cologne and sought to reclaim a sense of Heimat, including Moritz Goldschmitz, a synagogue representative who, asserted a tradition of Jewish localism. ${ }^{94}$ Those like Heinrich Böll who sought to remember the plight of Cologne's Jewish population were in the minority.

The appeal to Heimat as a source of cohesion in the rubble raises the question of how it differed from the idea of Volksgemeinschaft, which also sought community cohesion and similarly promised new postwar life. Yet while the promises of Volksgemeinschaft were made in terms of national struggle and mobilization for violence, postwar emphasis on Heimat focused on mobilizing local communities for the reconstruction of spaces for new private lives. ${ }^{95} \mathrm{Such}$ postwar community building, as Thießen notes, also differed in often being local, having no Führer, and in lacking the goal of racial homogeneity. ${ }^{96}$ Relinquishing national struggle and focusing on reconstructing local Heimat ultimately informed cultural demobilization, which had eluded Germans after 1918. ${ }^{97}$

\section{Locality, Nation and Postwar Democracy}


While Heimat offered a unifying point at a time of considerable division, it also proved useful in imagining a new democratic state. The limits of early West German democratization are well established, ranging from continuing undemocratic views of authority to persistent racial attitudes and lack of a critical press. Historians have further cited an apolitical emphasis on private life as an inhibitor of democratization. ${ }^{98}$ It could be tempting to situate popular desires for a local life of Heimat within such a narrative, but to do so would require we overlook not only how it involved the abandonment of national struggle as a redemptive force, but also how West Germans often described Heimat as essential to federalist democracy and used hometowns to forge new identifications. Notions of democracy as a local value did not suddenly do away with undemocratic practices and mentalities, but the forming of new identifications represented an important step in democratization.

From 1945 to the mid1950s, a time when the national political future seemed most openended, West German Heimat enthusiasts often wrote of how Heimat was crucial to federalism, decentring the nation, promoting political participation and preserving a democratic private sphere that would not be extinguished by ideology. The amateur Cologne historian Joseph Klersch is one such example. In the Weimar years Klersch had begun researching local history as a member of the Heimatverein Alt-Köln. During the Third Reich he had ceased publishing, but after 1945 he emerged as an avid advocate of democracy. He explained that the local could act as an 'elementary school of politics' that contrasted with mass political machines that blocked participation and made citizens into subjects. According to Klersch, local rootedness fostered democratic responsibility and inhibited the formation of passive masses that resulted in dictatorship. ${ }^{99}$ 'Real Heimat feeling', he argued, rallied against expansionary nationalism and 'massification' (Vermassung), which dehumanized individuals by reducing them to fungible 
parts of a mass to be used for political goals. Klersch simultaneously warned against 'false romanticism', ideology and ideas of the German village as a fountain of health. ${ }^{100}$ Klersch's fellow localist Max-Leo Schwering, the subsequent city museum director, advocate of confronting the local Nazi past, and son of a Centre Party politician, similarly argued that Heimat was important to democracy as it rallied against the creation of politically passive 'robotic masses' susceptible to dictatorship. ${ }^{101}$ Reference to 'massification' did form a semantic parallel with anti-democratic discourses which advocated against investing political power in the masses. ${ }^{102}$ Use of the term in Heimat discourses, however, often reveals the opposite concern: centralized political structures, Heimat enthusiasts often argued, shut out citizens from decisionmaking and treated populations as aggregated state resources. Greater federalism, many believed, offered an antidote.

Theories of the local as a democratic force had a counterpart in shifts in local identities. By the mid1940s, ideas of Cologne democracy appeared throughout popular discourses, drawing on reformulated historical memories and reinvented ritual tradition. Occasional associations of Rhenish identity with democracy had circulated since the early nineteenth century, though after 1945 they went from weak and inconsistent associations to broadly articulated tenets of local identity. ${ }^{103}$ A telling self-portrait of this development can be seen in a float from the carnival parade in 1950. Preceded by floats mocking Prussian militarism and rigidity and praising Adenauer as a local democratic hero, a float entitled 'Tünnies is being denazified' appeared. Here, Tünnies, the personification of Cologne, received medicines labelled 'anti-Nazin cream', 'anti-Nazin powder', 'Humanin' and 'Demokratin'. The float was a microcosm of the injection of newly perceived values into local identity. 
Reference to Cologne democracy appeared quite early in Heimat journals and underscored the value's role in shaping an uncertain future. Heimat publications emphasized key democratic local histories, including the city's medieval guild democracy (Zunftdemokratie) and anti-Prussianism. The year 1946 offered a convenient opportunity to celebrate the 550th anniversary of the city constitution of 1396, which had replaced an oligarchy of elite families with a 'guild democracy'. Localists linked the constitution to ideas of Cologne democracy and memorialized the history through theatrical performances and re-enactments. ${ }^{104}$ Heimat journals published histories of Cologne's guild democracy of 1396 and its connection to Cologne democracy, while locals emphasized how the buildings attached to this history, including the town hall and the Gürzenich, a festival hall, were symbols of their 'democratic local community'. ${ }^{105}$

Cologne's historic anti-Prussianism provided a particularly useful foil for local's development of ideas of Cologne democracy. Anti-Prussianism had circulated in the city to varying degrees since the nineteenth century and reached unprecedented heights after $1945{ }^{106}$ Evocation of anti-Prussianism had ambivalent results: its use to promote local identification with democracy also saw the shortcomings of local memory compounded, as it lent itself to the interpretation that Nazism came from the outside. The association of Prussianism with Nazism had been made not only by the regime, but also by its opponents. Inhabitants of Cologne contrasted local values, deemed to be anti-militarist, anti-hierarchy and democratic, with Prussian authoritarianism, militarism and rigid class structure. The Allies similarly emphasized the rejection of Prussian traditions as key to democratization and looked positively on popular anti-Prussianism in Cologne. In 1946 a British lieutenant wrote of emphasizing Rhenish tradition to turn away from dark Prussian histories. Germany needed to learn democracy, he argued, by 
encouraging individual personality and community and by abandoning soulless Prussian state machinery. ${ }^{107}$ This view harmonized with localist discourses that equated Prussia with massification and Cologne with a preference for a more human scale and mistrust of state machinery. ${ }^{108}$

Cologne Carnival, which the Nazis had appropriated for propaganda purposes, was saturated with themes related to Cologne democracy after 1945. Postwar citizens enhanced antiPrussian sentiments and discussed the tradition's democratic character, drawing in particular on the class-levelling and authority-challenging aspects of carnival and Cologne humour. ${ }^{109}$ As one local art historian argued, Cologne Carnival humour was anti-militarist, anti-hierarchical, antiPrussian and part of a life attitude associated with 'Rhenish democracy'. ${ }^{110}$ Heinrich Böll defined carnival as about a Cologne fondness for challenging class hierarchies — an idea that paralleled writings on Cologne as a city of 'trail-blazing social progress'. ${ }^{111}$ While carnival celebrations proved an effective forum for circulating ideas of local democracy, they contained little reflection on the history of carnival in the Third Reich beyond exaggerated narratives of carnival as a site of resistance. ${ }^{112}$

Identification with Cologne democracy had other shortcomings. Definition of what it meant in practice remained vague, which is perhaps unsurprising given the appeal of Heimat as a source of cohesion rather than contentious debate. Locals with different political leanings evoked 'Cologne democracy' without specifying in detail what the term meant and how it related to specific party platforms. ${ }^{113}$ The most glaring problem was avoidance of confrontation over responsibility for the Nazi past. While authors writing about Cologne democracy seldom argued that its existence countered accusations of local guilt, that unspoken implication likely added to its appeal. Adenauer's argument that Cologne had been the most bombed-out city that had least 
deserved its destruction also reflected an unwillingness to acknowledge the city's culpability. ${ }^{114}$ Yet if repression of the past was the primary goal, it is surprising that Heimat enthusiasts often neglected more exculpatory histories - for example the fact that support for the Nazis at the polls across Germany had been lowest in Cologne-Aachen in all three elections in 1932 and 1933. ${ }^{115}$ Supporters of the concept of Cologne democracy also included those with little interest in repressing the past. Böll, one of the strongest advocates of examining local guilt, strongly associated Prussia with Nazism and promoted notions of a Cologne democratic tradition. ${ }^{116}$ In 1947 Paul Wolfsohn, a Jewish book dealer in Cologne, similarly wrote in the Heimat journal AltKöln of the numerous 'democratic' histories of Cologne, whose loss he viewed as 'tragic' and which he argued needed to be recovered. ${ }^{117}$

Written discourses focused on the open-ended questions of political reconstruction and reimagining the nation. Heimat was not concerned only with ideas of nationhood, though its role in imagining nation extended back generations. The relationship of region to nation, was historically contingent, ranging anywhere from nationalist affirmation to separatism. ${ }^{118}$ Many postwar Heimat enthusiasts went to neither extreme, promoting instead the notion that Heimat modified the national idea by containing its excesses. In an article memorializing the local history of 1848 , Klersch argued that the Rhinelander should draw on local democratic histories to reject statist nationalism. ${ }^{119} \mathrm{He}$ argued for 'real Heimat feeling' as local and in opposition to an expansionary nationalist idea. ${ }^{120}$ Such notions reflected not rejection of the national idea but its reimagining. In turn, the Rhenish politician Karl Arnold, who had been hounded by the Gestapo during the Nazi years, argued that a state rooted in Heimat was the 'antithesis of modern nationalism' ${ }^{121}$ 
By the mid1950s, as the new Federal Republic increasingly proved its stability, the feverish discourse on Heimat as essential for reimagining federalist democracy began to wane. The notion of Cologne democracy, by contrast, became firmly established as a component of local identity. In part because of its vagueness, Cologne democracy was evoked in similar form throughout the 1950s and beyond, though the sense of pressing need of the immediate postwar years was gradually reduced. Throughout the 1960s and 1970s, Heimat enthusiasts continued to describe Cologne Carnival as a democratic tradition and their medieval guild democracy as a pillar of Cologne's democratic tradition with which citizens should identify. ${ }^{122}$ These decades similarly saw continued reference to local 'openness to the world' - a notion that also came to prominence in the immediate postwar years.

\section{Openness to the World, Tolerance and Heimat as a Human Metaphor}

In October 1944 a Nazi propaganda newspaper article entitled 'The Watch on the Rhine' declared, 'The Rhinelander does not feel himself to be western nor eastern, but German.' ${ }^{123}$ After the war, changes in popular perception of the relationship of locality, nation and Europe were nowhere more apparent than in the rapid disappearance of the nationalist trope of 'the Watch on the Rhine' and its replacement with the notion of Cologne as a western bridge and as open to the world. Both local politicians and Heimat enthusiasts appropriated these ideas to advance notions of the Rhineland as a cornerstone of western European unity. In constructing ideas of Cologne openness to the world, localists drew on histories of trade, outsider integration and international influence as well as Roman histories and pre-national histories_-including the conservative notion of Cologne as a centre of the Christian Occident (Abendland). 
As early as 1946 Heimat enthusiasts and city officials evoked these ideas at the weeklong 'Cologne Culture Days'. The proceedings included a host of events, speeches and localhistory exhibitions and the unveiling of the museum for the Roman relics whose discovery underneath the rubble had come at an opportune moment. With the theme 'The Rhine and Europe', the Culture Days were filled with tropes of Cologne as a European city and centre of Christian occidental culture that would reawaken the European idea by harnessing the city's mixture of Roman and German traditions. ${ }^{124}$ City reports held that events demonstrated the dedication of Cologne's citizens to 'international understanding on a cultural basis'. ${ }^{125}$ From the Culture Days to the cathedral anniversary in 1948, Heimat enthusiasts wrote prolifically on openness and Europeanness as local values rooted in history and geography. As an article in the Heimat journal Unser Köln noted, Rhinelanders did feel themselves to be German, but they also had a 'European and open-to-the-world feeling'. ${ }^{126}$

The role of Heimat in tempering but not rejecting nation also shaped the cathedral anniversary. Organizers framed events in terms of the victory of a European-German tradition over a nationalist one, though the Abendland idea made a notable appearance. ${ }^{127}$ Into the $1950 \mathrm{~s}$ localists continued to use major events to promote ideas of Cologne's Europeanness, including the 1,900th anniversary of the city and the Europa-Union Deutschland society congresses held in Cologne in 1950 and 1954. The society advocated a federalist vision of European unification, and the congresses were shepherded to Cologne by Friedrich Carl von Oppenheim, a Jewish Cologne banker, Europeanist and local patriot who referred to his own nationality as a 'Cologne European'. Oppenheim built one of the largest Europa-Union branches in Cologne and invited politicians from the Social Democratic Party to speak at its congresses about Cologne's Europeanness. ${ }^{128}$ 
The notion that a dual focus on locality and European unity would moderate the national idea was a departure from Nazi visions of Europe and could also be found in the Hanseatic cities and, as Christian Bailey has demonstrated, in the southern German states. ${ }^{129}$ Shortcomings were apparent, however, as local-European identifications re-enforced divisions with the East. While studies have illustrated how expellee evocations of Heimat bolstered the Cold War divide, West Germans also cast the Eastern bloc as a space of anti-Heimat. ${ }^{130}$ As Karl Arnold argued at the Rhenish Heimat Day in 1953, the USSR's mistreatment of non-Russian minorities and uprooting of populations based on state and economic imperatives illustrated Soviet hostility to Heimat. ${ }^{131}$ Evoking the Abendland meant drawing on an idea popular among anti-liberal groups, although its evocation did not equate to being anti-democratic. ${ }^{132}$ As Hans Peter, rector of the University of Cologne, later argued, the term had divergent political interpretations, with Cologne embodying in his mind the 'spirit of the Abendland' so long as one used the term to refer to the 'soul of contemporary European culture'. ${ }^{133}$

Beyond European unification, ideas of local openness proved useful for groups of more inclusively-minded localists who appropriated it to argue against the ongoing exclusion of outsiders. Since at least the nineteenth century, exclusionary ideas of local belonging had circulated, including notions of the Alt-Kölner, Eingesessene and Alteingesessene, which indicated the duration of familial ties to the city. Expellees in particular faced discrimination. Cologne Heimat enthusiasts, however, could be found among those arguing for greater inclusion. Cologne-dialect expert Adam Wrede reflected this attitude in an article published in 1948 on promoting local culture, which argued for embracing expellees and outsiders as both a practice of local tradition and an essential postwar task. Cologne, he noted, was historically adept at harmonizing tradition, change and an influx of outsiders, and he pointed to the local integration 
of twelfth-century foreign artisans and sixteenth-century Dutch refugees. ${ }^{134}$ Klersch, who wrote prolifically on giving expellees a new Heimat, promoted similar ideas of a Cologne tradition of forbearance and openness to the world that attracted outsiders and made Cologne Heimat for them. ${ }^{135}$

Carnival celebrations offered a particularly important venue for promoting ideas of local openness. As early as 1949 locals who supported inclusivity used the Cologne Carnival to express ideas of the city as balancing local rootedness and openness to the world. ${ }^{136}$ Carnival princes declared in speeches that their carnival state was 'the most tolerant democracy of the world' and that outsiders could become Cologners by participating in the tradition. Carnival organizers proposed that the tradition be deployed to win outsiders' affections. ${ }^{137}$ In forging conceptions of carnival as inclusive, locals hamessed the tradition's participatory nature, individual indulgence and ecstatic performance of community. ${ }^{138}$ They also reinterpreted carnival ideas, including that of the Jeck (a fellow celebrant), as embodying 'tolerance' and a 'right to individuality'. ${ }^{139}$ At the same time, exclusionary attitudes could be easily found, as displayed by one local woman who argued that only natives of Cologne should participate in the women's carnival day, which challenged male authority. ${ }^{140}$ The tradition also included a host of rituals foreign to the uninitiated. Emphasis on inclusion through carnival also overlooked the Cologne Carnival's role in exclusion in the Third Reich and the presence of former Nazis within carnival societies. ${ }^{141}$

Localists who argued for integration also articulated ideas of Heimat as a human metaphor, rather than a specifically German concept. As one Cologne localist argued in 1950 Heimat described peoples' relationship to places of home across the globe and it would be 'arrogant' to claim Heimat as simply a German phenomenon. ${ }^{142}$ In 1954 , one speaker addressing 
the subject of Heimat and young people at the Rhenish Heimat Day argued that when understood as a human experience, Heimat contained a key to openness to the world. ${ }^{143}$ Attempts to shape more inclusive notions of local community, however, should not be viewed uncritically. Such identifications often lacked sophistication and, like ideas of local democracy, magnified failures to confront the local Nazi past. Exclusionary practices continued, while locals who favoured inclusivity were of their time and their support for tolerance had limits. As an article that appeared in the Kölnische Rundschau in 1956 recounted, while they welcomed outsiders, natives should retain their majority. ${ }^{144}$

By the late 1950s and 1960s, discourses on local openness and tolerance centred increasingly on immigration. Reflecting this focus, one speaker at the Rhenish Heimat Day in 1965 noted that historically immigrants had come to the Rhineland from diverse areas and had become natives within a few generations. Drawing on the Rhineland's Roman history, the speaker argued that those who had emigrated from the Mediterranean had historically enriched the Rhinelander's regional culture-a clear reference to new Italian immigrants in the region. The Heimat society that sponsored the Rhenish Heimat Day officially aimed to help immigrants find a second Heimat in the Rhineland. ${ }^{145}$ Throughout the 1960s politicians and Heimat enthusiasts increasingly promoted notions of Cologne's 'tolerant open-to-the-world spirit' and 'power of assimilation', while arguing for use of traditions like the carnival to integrate newcomers. ${ }^{146}$ Immigration also became an issue in Heimatkunde, with the youth Heimat journal Jung-Köln appealing to Heimat as a human experience to encourage local children to help immigrant children find a new Heimat in the city By imagining the loss of one's own Heimat, such pieces argued, one could develop sympathy with the displaced. ${ }^{147}$ Such efforts hardly did away with significant ongoing discrimination, and failures to perform claimed values of 
openness could leave locals open to challenge. In 1964 one student advocate of immigrant rights, for example, argued that discrimination against international students in Cologne was not in accord with 'Cologne openness to the world' and must be stopped. ${ }^{148}$

Tropes of local tolerance persisted for decades after the 1960s. Although the notion of Heimat was challenged throughout the 1960s as the result of the convergence of a complex series of generational, economic and political factors, the 1970s and 1980s saw a renaissance of the concept. More recently, perceptions of 'Cologne tolerance' have been deployed in advocacy for greater acceptance of both immigrants and the city's large gay and lesbian population. Appeals to local tolerance have also appeared in mass events against right-wing radicalism and violence against immigrants. ${ }^{149}$ While the tropes of local identity promoted in the early postwar years have had dynamic afterlives, ideas like local tolerance and openness remain proscriptive tools in attempts to advance more inclusive notions of local community amidst the realities of ongoing discrimination.

\section{Conclusion}

Following the defeat of Germany in the Second World War, a range of factors triggered a popular turn to local Heimat, including cataclysmic destruction of the home front, elimination of the nation as a political actor, desires for local, private lives and the need for new sources of identification. Social divisions in the aftermath of war, the challenges of reconstruction and traumatic experiences increased desires for local community. In probing local discourses after 1945, we find that a host of observers noted how desires for Heimat reached unprecedented heights. Moreover, popular desire for Heimat centred less on the bucolic stereotypes of Heimat films and more on actual lost places of home and their reconstruction. 
As local discourses in early postwar Cologne demonstrate, Heimat was not simply about promoting a sense of suffering. It was also tied to recovery and imagining a life after death, with the local emerging as a focal point for repairing biographic rupture, rebuilding, and forging social cohesion. Efforts to achieve such cohesion included the bridging of confessional and political partisanship and avoidance of the divisive question of guilt for the Nazi past. While the Volksgemeinschaft idea had offered redemption through mobilization for violence and national struggle, the postwar emphasis on local reconstruction and a return to Heimat as a route to a new life ultimately contributed to cultural demobilization. The local turn, however, did not mean abandonment of a national identity and Heimat was often couched in terms of modifying and decentring, but not displacing, the nation. Many further argued that local orientation was crucial to federalism, democratic participation and preventing a new dictatorship.

Local Heimat also offered a flexible source of identity. In the immediate postwar years, the idea of democracy as a local value began to circulate in Cologne, as it did also in many other West German regions. Localists forged the concept of Cologne democracy by reformulating local historical memory and reinventing local tradition. These ideas of local democracy remained vague and existed alongside significant problems in democratic practice, while also compounding failures to confront local culpability for the Nazi past. At the same time, they helped counter the potentially hazardous idea that democracy was foreign to their own identities. Ideas of 'Cologne openness to the world' and, later, 'Cologne tolerance' also emerged in early postwar discourses, proving useful for efforts to foster identification with European unification and refashion understandings of the relationship between the locality, the nation and Europe. The idea of the Rhineland as a 'bridge' to the West displaced older nationalist narratives of the 'Watch on the Rhine', while increasing divisions vis-à-vis the East. Localists drew on 
Christian histories, international influence on their region and their location on the western border of Germany to bolster these new narratives of space. Inclusively-minded localists appropriated histories of influx of outsiders and used ideas of local openness and tolerance to encourage greater integration of expellees and immigrants. They also marshalled Heimat as a human metaphor to generate more sympathy with the displaced who faced ongoing discrimination. These notions of local identity remained proscriptive, existing alongside many ongoing exclusions. It was the reality of such exclusions that made such identifications useful tools. New identity claims did not suddenly make citizens adept practitioners of democracy, and reforming underlying mentalities would prove a decades-long process. Yet, new understandings of Heimat and local identity aided the adoption of new identifications and generated greater receptivity at a time when the establishment of a stable democracy was hardly a foregone conclusion.

Friedrich-Alexander-Universität Erlangen-Nürnberg jeremy.j.dewaal@fau.de

\section{Figure}




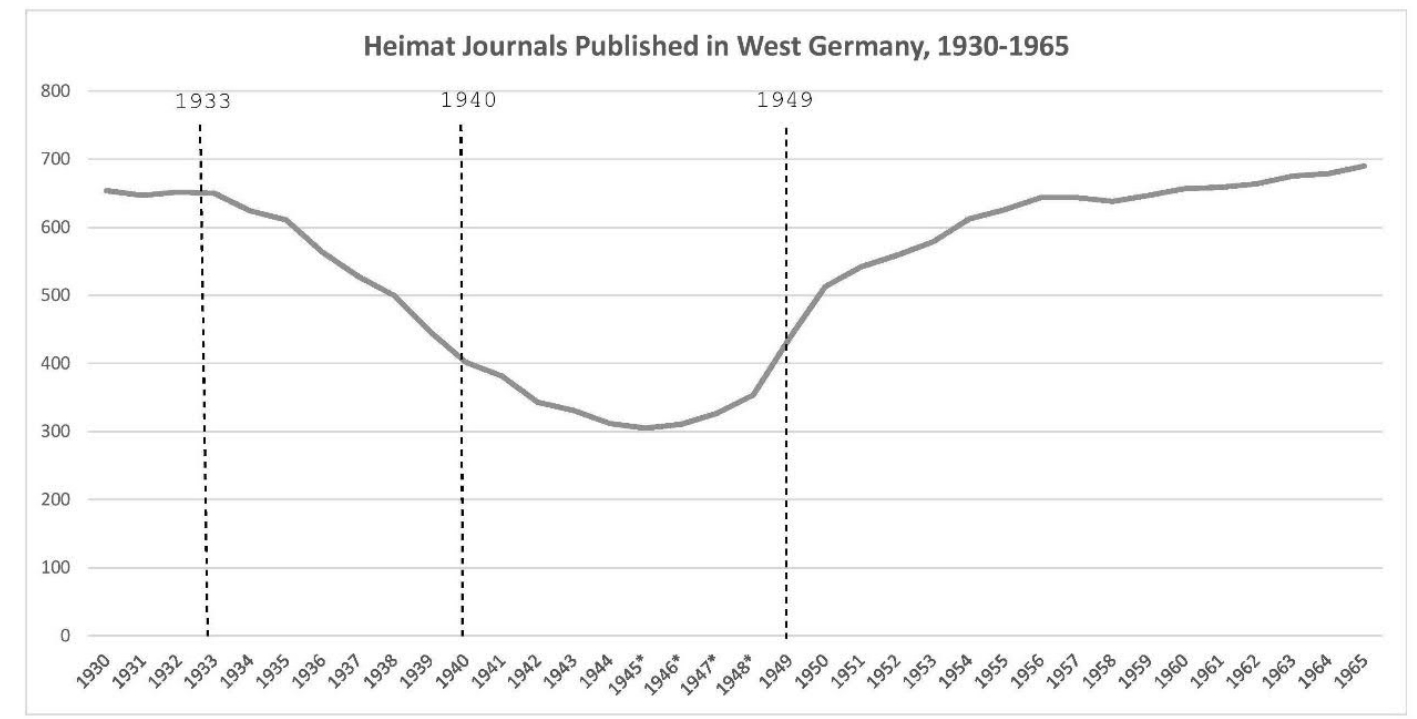

Figure 1: Publication of Heimat Journals in West Germany (including the Saarland, not including West Berlin) from 1930 to 1965 . Tallies compiled from an analysis of Rudi Mechthold's index of Heimat journals.

*Based on publications from established presses. Does not include the ephemeral and selfpublished Heimat journals that thrived in the immediate postwar years.

Source: Rudi Mechthold (ed.), Landesgeschichtliche Zeitschriften 1800-2009: Ein Verzeichnis deutschsprachiger landesgeschichtlicher und Heimatkundlicher Zeitschriften, Zeitungsbeilagen und Schriftenreihen (Frankfurt, 2011).

\footnotetext{
* The author would like to thank Celia Applegate, Helmut Walser Smith and the anonymous reviewers for their helpful comments. Thanks are also owing to the Deutscher Akademischer Austauschdienst and the Alexander von Humboldt Foundation.

${ }^{1}$ Otto Feger, Konstanz: aus der Vergangenheit einer alten Stadt (Constance, 1947), p. 11.
} 
${ }^{2}$ Jeremy DeWaal, Redemptive Geographies: The Turn to Local Heimat in West Germany

(Doctoral Dissertation, Vanderbilt University, 2014), 142-192.

${ }^{3}$ Max Brauer, 'Rede am 22. November 1946', in Max Brauer, Nüchternen Sinnes und Heissen Herzens (Hamburg, 1956), pp. 24-5.

${ }^{4}$ DeWaal, Redemptive Geographies, 90-141.

${ }^{5}$ Statistisches Amt der Stadt Köln, Verwaltungsbericht der Stadt Köln, 1945/47 (Cologne, 1947), pp. 54-5.

${ }^{6}$ Celia Applegate, A Nation of Provincials: The German Idea of Heimat (Berkeley, 1990); Jörg Arnold, The Allied Air War and Urban Memory: The Legacy of Strategic Bombing in Germany (Cambridge, 2011); Jan Palmowski, Inventing a Socialist Nation: Heimat and the Politics of Everyday Life in the GDR, 1945-90 (Cambridge, 2009).

${ }^{7}$ For only a few examples of works that reference Heimat as tainted immediately after 1945, see Beate Herget and Berit Pleitner, 'Heimat im Museum?' in Beate Herget and Berit Pleitner (eds), Heimat im Museum? (Munich, 2008), pp. 9-24; Jens Korkampf, Die Erfindung der Heimat (Berlin, 2006); Christopher Wickham, Constructing Heimat in Postwar Germany: Longing and Belonging (Lampeter, 1999), p. 7; Wolfgang Lipp, 'Heimatbewegung, Regionalismus, Pfade der Modern', in Willi Cremer and Ansgar Klein (eds), Heimat: Analysen, Themen, Perspektiven, vol. 1 (Bielefeld, 1990), pp. 135-54.

${ }^{8}$ Willi Oberkrome, Deutsche Heimat: nationale Konzeptionen und regionale Praxis von Naturschutz, Landschaftsgestaltung und Kulturpolitik in Westfalen-Lippe und Thüringen (Paderborn, 2004); Habbo Knoch (ed.), Das Erbe der Provinz: Heimatkultur und Geschichtspolitik nach 1945 (Göttingen, 2001); Petra Behrens, Regionale Identität und Regionalkultur in Demokratie und Diktatur (Baden-Baden, 2014).

${ }^{9}$ Alon Confino, Germany as a Culture of Remembrance: Promises and Limits of Writing History (Chapel Hill, 2006).

${ }^{10}$ Johannes von Moltke, No Place Like Home: Locations of Heimat in German Cinema (Berkeley, 2005). 
${ }^{11}$ For arguments on Heimat as regressive see Werner Hartung, Konservative Zivilisationskritik und regionale Identität (Hanover, 1991); Peter Blickle, Heimat: A Critical Theory of the German Idea of Homeland (Rochester, N.Y., 2002); Martina Steber, Ethnische Gewissheiten: die Ordnung des Regionalen im bayerischen Schwaben vom Kaiserreich bis zum NS-Regime (Göttingen, 2010).

${ }^{12}$ For an example of this narrative see Wolfgang Benz, Auftrag Demokratie: die Gründungsgeschichte der Bundesrepublik und die Entstehung der DDR 1945-1949 (Berlin, 2009).

${ }^{13}$ See Ulrich Herbert (ed.), Wandlungsprozesse in Westdeutschland: Belastung, Integration und Liberalisierung, 1945-1980 (Göttingen, 2002); Konrad Jarausch, Die Umkehr: deutsche Wandlungen, 1945-1995 (Munich, 2004); Manfred Görtemaker, Geschichte der Bundesrepublik Deutschland: von der Gründung bis zur Gegenwart (Munich, 1999).

${ }^{14}$ On democratization as a search for meaning and 'life form' see Daniel Fulda et al., 'Zur Einführung', in Daniel Fulda et al. (eds), Demokratie im Schatten der Gewalt: Geschichte des Privaten im deutschen Nachkrieg (Göttingen, 2010), pp. 7-24; Paul Nolte, Was ist Demokratie? Geschichte und Gegenwart (Munich, 2012).

${ }^{15}$ On incomplete cultural demobilization after 1918, see John Horne, 'Kulturelle

Demobilmachung 1919-1939: Ein sinnvoller historischer Begriff?‘, in Wolfgang Hardtwig (ed.), Politische Kulturgeschichte der Zwischenkrieg szeit 1918-1938 (Göttingen, 2005), pp.129-50.

${ }^{16}$ Katherine Aaslestad, Place and Politics: Local Identity, Civic Culture and German Nationalism in North Germany during the Revolutionary Era (Boston, 2005); Siegfried Weichlein, Nation und Region: Integrationsprozess im Bismarckreich (Düsseldorf, 2004); Alon Confino, Nation as a Local Metaphor: Württemberg, Imperial Germany and National Memory, 1871-1918 (Chapel Hill, 1997).

${ }^{17}$ Peter Fritzsche, 'Cities Forget, Nations Remember: Berlin and Germany and the Shock of Modernity', in Paul Betts and Greg Eghigian (eds), Pain and Prosperity: Reconsidering Twentieth-Century German History (Stanford, 2003), pp. 35-59. 
${ }^{18}$ For debates on Nazism and Heimat, see Claus-Christian Szejnmann and Maiken Umbach (eds), Heimat, Region and Empire: Spatial Identities under National Socialism (Basingstoke, 2012); Applegate, Nation of Provincials, pp. 197-227.

${ }^{19}$ Jeremy Noakes, 'Federalism in the Nazi State', in Maiken Umbach (ed.), German Federalism: Past, Present, Future (Basingstroke, 2002), pp. 113-45; Michael Kissener, 'Nationalsozialismus und Widerstand', in Katharina Weigand (ed.), Heimat: Konstanten und Wandel (Munich, 1997), pp. 210-11.

${ }^{20}$ Martina Steber, 'Regions and National Socialist Ideology: Reflections on Contained Plurality', in Szejnmann and Umbach, Heimat, Region, and Empire, pp. 25-42; Catherine Epstein, 'Germanization in the Warthegau: Germans, Jews and Poles in the Making of a "German" Gau', in Szejnmann and Umbach, Heimat, Region, and Empire, pp. 93-111; On the ideological receptivity of Heimat societies see Thomas Schaarschmidt, Regionalkultur und Diktatur: sächsische Heimatbewegung und Heimatpropaganda im Dritten Reich und in der SBZ/DDR (Cologne, 2004); Oberkrome, Deutsche Heimat, pp. 141-232; Applegate, Nation of Provincials, pp. 197-227.

${ }^{21}$ Julia Faehndrich, 'Entstehung und Aufstieg des Heimatbuchs', in Matthias Beer (ed.), Das Heimatbuch: Geschichte, Methodik, Wirkung (Göttingen, 2010), pp. 62-72.

${ }^{22}$ Dietrich Klagges, Geschichtsunterricht als nationalpolitische Erziehung (Frankfurt, 1937), pp. $165-7$.

${ }^{23}$ The Heimat society's calendar and journal ceased to appear in 1933. The regime used Jung$K o ̈ l n$ for propaganda until its final edition in 1934.

${ }^{24}$ Marcus Leifeld, Der Kölner Karneval in der Zeit des Nationalsozialismus (Cologne, 2015); Carl Dietmar and Marcus Leifeld, Alaaf und Heil Hitler: Karneval im Dritten Reich (Munich, 2010).

${ }^{25}$ These themes can be found extensively from 1933 to 1942 in volumes ten to nineteen of the Rheinische Blätter.

${ }^{26}$ Robert Brandes, 'Der Kampfbund im Rheinland', Rheinische Blätter, 10, 10 (Oct. 1933), pp. 909-12. 
${ }^{27}$ Malthe Thießen, Eingebrannt ins Gedächtnis: Hamburgs Gedenken an Luftkrieg und Kriegsende, 1943 bis 2005 (Munich, 2007), pp. 35-94.

28 'Heimat und Front sind eins', Westdeutscher Beobachter, 3 May 1940.

29 'Von den britischen Kulturschändern vernichtet', Westdeutscher Beobachter (1 June 1942);

'Vergeltung für Köln', Westdeutscher Beobachter (1 June 1942); 'Churchills Krieg gegen Frauen und Kinder', Westdeutscher Beobachter (2 June 1942); 'Die britische Kulturschande',

Westdeutscher Beobachter (7 June 1942).

${ }^{30}$ Letters reprinted in Martin Rüther, Köln im Zweiten Weltkrieg (Cologne, 2005), pp. 290-1.

31 'Gefährdete Heimat', Westdeutscher Beobachter (28 Dec. 1944); 'Kölner auf einsamen

Stützpunkten', Westdeutscher Beobachter (5 Apr. 1944); 'Von rechter und falscher

Heimattreue', Westdeutscher Beobachter (18 Jan. 1945).

${ }^{32}$ Nicholas Stargardt, The German War: A Nation under Arms, 1939-45 (London, 2015).

${ }^{33}$ Was soll aus dem Rheinland werden?', Westdeutscher Beobachter (16 Oct. 1944); 'Gefährdete Heimat', Westdeutscher Beobachter (28 Dec. 1944); 'Haß!', Westdeutscher Beobachter (19 Oct. 1944); 'Köln, die Frontstadt', Westdeutscher Beobachter (19 Oct. 1944).

${ }^{34}$ On local manifestations of Volksgemeinschaft, see Dietmar von Reeken and Malte Thießen (eds), 'Volksgemeinschaft' als soziale Praxis: neue Forschungen zur NS-Gesellschaft vor Ort (Paderborn, 2013).

${ }^{35}$ Ian Kershaw, 'Volksgemeinschaft: Potential and Limitations of the Concept', in Martina Steber and Bernhard Gotto (eds), Visions of Community in Nazi Germany: Social Engineering and Private Lives (Oxford, 2014), pp. 29-42; Richard Bessel, 'The End of the Volksgemeinschaft', in Steber and Gotto, Visions of Community, pp. 281-94; Neil Gregor, 'A Schicksalsgemeinschaft? Allied Bombing, Civilian Morale, and Social Dissolution in Nuremberg, 1942-1945', Historical Journal, 43, 4 (2000), pp. 1051-70; Malte Thießen, 'Erinnerungen an die "Volksgemeinschaft": Integration und Exklusion im kommunalen und kommunikativen Gedächtnis’, in Detlef Schmiechen-Ackermann (ed.), 'Volksgemeinschaft': Mythos wirkungsmächtige soziale Verheißung oder soziale Realität im 'Dritten Reich'?: Zwischenbilanz einer kontroversen Debatte (Paderborn, 2012), pp. 319-34. 
${ }^{36}$ Wilfried von Bredow and Hans-Friedrich Foltin, Zwiespältige Zufluchten: zur Renaissance des Heimatgefühls (Bonn, 1981), p.16.

${ }^{37}$ Peter Felten, 'Erinnerungen eines achtzigjährigen Kölner Arztes' (1943), Alt-Köln, 5, 14 (Nov. 1951), pp. 53-5.

${ }^{38}$ Willy Klett, 'Ming einzig Kölle' (1943), in Reinold Louis, Kölnischer Liederschatz (Cologne, 1986), p. 174.

${ }^{39}$ On carnivalistic engagement with the legend, see "Patentwohnung für evakuierte Kölsche,"

Kölner Rosenmontagszeitung, 1954.

${ }^{40}$ Peter Hasenberg, Ist das erst 15 Jahre her?: die ersten Nachkriegsjahre im Spiegel der Zeitung (Cologne, 1960), p. 13.

${ }^{41}$ See, for example, Florian, Köln, 8; Interview of Günther Hochgürtel in Unser Köln:

Erinnerungen 1910-1960, (ed.) Anja vom Stein (Erfurt, 1999), p.80.

${ }^{42}$ Wilhelm Staffel, Willi Ostermann (Cologne, 1976), pp. 84-5.

${ }^{43}$ Goswin Gath, 'Erinnerunge', in Goswin Gath, Draum un Spill (Cologne, 1947), p. 39.

${ }^{44}$ Reprint of early postwar poems: Anton Stille, 'D'r Letzte Ress' and 'No lange Johre', in Anton Stille, Kölsche Blömcher (Cologne, 1960), p. 17.

45 'Köln wird auferstehen', Kölnischer Kurier (9 Apr. 1945).

${ }^{46}$ 'Nein, es muß Köln sein!', Kölnische Rundschau (11 Oct. 1946).

47 'Lob für ein Amt', Westdeutsche Zeitung (19 Jan. 1949).

${ }^{49}$ Heinrich Böll, 'Stichworte', in Heinrich Böll, Werke, Kölner Ausgabe, 14, ed. Jochen Schubert (Cologne, 2002), p. 314.

50 'Heimatliche Melodie', Kölnischer Kurier (14 Aug. 1945).

${ }^{51}$ Richard Bessel and Dirk Schumann (eds), Life after Death: Approaches to a Cultural and Social History of Europe during the 1940s and 1950s (Cambridge, 2003); Richard Bessel, 1945: From War to Peace (London, 2009).

${ }^{52}$ Neil Gregor, Haunted City: Nuremberg and the Nazi Past (New Haven, 2008).

${ }^{53}$ Thießen, Eingebrannt ins Gedächtnis; Arnold, Allied Air War. 
54 'Vorträge im Heimatverein Alt-Köln', Unser Köln, 2 (1948), p. 4.

${ }^{55}$ Albrecht Bodde, 'Kölle_es war einmal' (1945), in Louis, Liederschatz, p. 188.

56 Joachim Hening, 'Köln du kannst niemals untergehn' (1945), Karl Jahn, 'Ming Heimat'

(1946), Jupp Schmitz, 'Ming herrlich Kölle' (1949), in Louis, Liederschatz, pp. 176, 178, 189;

Wilhelm Stumpf, ‘Kölle, domols un jetz’, Rheinische Zeitung (9 Feb. 1949).

${ }^{57}$ Rudolf Roonthal, 'Köln, mein Köln, du wirst wiedererstehn', in Louis, Liederschatz, p. 187.

${ }^{59}$ Waldemar Cosson, 'Treuschwur', in Kölsche Klaaf, (ed.) Waldemar Cosson (Cologne, 1951), p.6.

${ }^{60}$ Heinrich Schroder, Colonia Deleta (Cologne, 1947), pp. 68-74.

61 'Das Amt für kölnisches Volkstum', Unser Köln, 5/6 (1948), p. 13.

${ }^{62}$ Joseph Klersch, 'Unsere Heimat-Vereine', Alt-Köln, 1, 1 (Aug. 1947), p. 4.

${ }^{63}$ Excerpts from Robert Grosche, Konrad Adenauer and Hans Jonen, Alt und Neu-Köln (1946),

p. 2.

${ }^{64}$ Statistisches Amt der Stadt Köln, Verwaltung sbericht, 1945/47, p. 50.

${ }^{65}$ Kurt Koszyk, 'Presse und Pressekonzentration in den 50er Jahren', in Axel Schildt and Arnold Sywottek (eds), Modernisierung im Wiederaufbau: die westdeutsche Gesellschaft der 50er Jahre (Bonn, 1993), p. 441.

66 'Zum Geleit', Alt-Köln, 1 (Aug. 1947), p. 1.

67 'Lob für ein Amt', Westdeutsche Zeitung (19 Jan. 1949); Statistisches Amt der Stadt Köln, Verwaltungsbericht, 1945/47, pp. 54-5.

${ }^{68}$ Hans Jonen, 'Kölsche sin nit klein zo krigge' (1948), in Louis, Liederschatz, p. 229; Kölsche Grielächer, 25 Jahre Karnevals-Gesellschaft (Cologne, 1952), p. 6; Hans Jonen, Fünfzig Jahre Rubbedidupp (Cologne, 1952), pp. 66-7, 99-109.

${ }^{69}$ Joseph Klersch, Kölner Fastnachtsspiegel (Cologne, 1948), pp. 134-7; Albrecht Bodde, 'Zum Geleit', in ibid., i.

${ }^{70}$ Quotation from 'So fingen wir wieder an!', Westdeutsche Zeitung (4 Feb. 1949). See also 'Das Amt für kölnisches Volkstum', Unser Köln, 5/6 (1948), p. 13; Gerhard Ebeler, 'Meer losse de Flögele nit hange', in Louis, Liederschatz, p. 183. 
${ }^{71}$ Lis Böhle, 'Widder doheim', Kölnischer Kurier (14 Aug. 1945); Lis Böhle and Willy Key, Skizzierte Erinnerungen (Cologne, 1947), p. 31; Lis Böhle, 'Domols un hück', in Lis Böhle, Jeck op Kölle (Cologne, 1955), p. 192; Lis Böhle, Kölsche Saison (Cologne, 1963), pp. 107-12.

72 'Brauchtumswunderkind', Rosenmontagzeitung, 1961.

73 Adam Wrede, 'Kölsche Seele-Kölsche Art', Kölner Almanach (1954/55), pp. 299-300.

${ }^{74}$ Joseph Klersch, Volkstum und Volksleben in Köln (Cologne, 1965), pp. 26-8.

${ }^{75}$ Konrad Adenauer excerpt, Kölner Almanach (1965/66), p. 8.

${ }^{76}$ On use of Heimat to bridge across partisanship and other divisions, see Applegate, Nation of

Provincials; Confino, Nation as a Local Metaphor.

${ }^{77}$ Heinz Weber, 'Ich mööch noch ens' (1943/44), in Heinz Weber (ed.), Kölsche Verzällcher för Hären un Mamsellcher (12th edn, Cologne, 2007; 1st edn, 1964), p. 205.

${ }^{78}$ Bundesarchiv Koblenz, Plak 004-006-007, Apr. 1947.

${ }^{79}$ Generalvikariat Köln, Handbuch des Erzbistums Köln, vol. 2 (Cologne, 1966), p. 18.

${ }^{80}$ Thomas Brodie, 'The German Catholic Diaspora in the Second World War', German History, 33, 1 (2015), pp. 80-99; Joseph Kardinal Frings, 'Hirtenwort', Kirchlicher Anzeiger für die Erzdiözese Köln (hereafter KAEK), 86 (15 Nov. 1946), pp. 293-5.

${ }^{81}$ Joseph Kardinal Frings, 'Warnung vor verwerflichen Vergnügen', KAEK, 88 (15 Feb. 1948), pp. 41-2.

82 'Was ist des Menschen Heimat?', Kirchenzeitung für das Erzbistum Köln (hereafter KEK) (23 Jan. 1949), pp. 13-4; 'Die Gattin und die Mutter', KEK (6 July 1947), p. 84; 'Brief an einen Gefangenen', KEK (25 Dec. 1947), p. 170; 'Die Not der heimatlosen Seele', in 'Predigtmaterial', KAEK, 92 (15 May 1952).

${ }^{83}$ Historisches Archiv des Erzbistums Köln (hereafter HAEK), MK, Nr. 2282, H. Rode, 'Einleitung'.

${ }^{84}$ HAEK, MK, Nr. 2283, Heinz Wolf, 'Kölner Dom vor der Entpreußifizierung: keine Konjunktur für Nationaldenkmäler', Rhein-Echo (8 June 1948).

${ }^{85}$ Kölnische Rundschau, Der Domes Ruf (Cologne, 1948), pp. 5-6.

${ }^{86}$ W. Henkels, 'Brief an eine Kölnerin, das Heimweh betreffend', and Liz Böhle, 'Flucht und Heimat', in Stadt Köln (ed.), Köln und sein Dom (Cologne, 1948), pp. 11-14, 23-4; Hans Vogts, 
'Die Schicksalstunde der Rheinischen Kunst', in Zentral-Dombau-Verein (ed.), Der Kölner Dom (Cologne, 1948), p. 50; Fritz Franz Florian [pseud., Hans Schmitt], Köln am Rhein (Cologne, 1955), p. 7-8.

${ }^{87}$ HAEK, MK, Nr. 2283, 'Kölner Dom vor der Entpreußifizierung', Rhein-Echo (8 June 1948); Nr. 2284, 'Der Dom als Wahrzeichen', Rheinische Zeitung (14 Aug. 1948); H. Zintgraff-Grosse, ‘Köln und der Kölner Dom', Der Ruf (15 Aug. 1948).

${ }^{88}$ HAEK, MK, Nr. 2283, 'Über Trümmern das alte Herz', Telegraf Berlin (3 Aug. 1948).

${ }^{89}$ Gregor, Haunted City.

${ }^{90}$ Jürgen Zieher, 'Im Schatten von Antisemitismus und Wiedergutmachung', in Jost Dülffer (ed.), Köln in den 50er Jahren: zwischen Tradition und Modernisierung (Cologne, 2001), pp. 277-304; Jeffry Diefendorf, 'Reconciling Competing Pasts in Postwar Cologne', in Gabriel Rosenfeld and Paul Jaskot (eds), Beyond Berlin: Twelve German Cities Confront the Nazi Past (Ann Arbor, 2008), pp. 48-66.

${ }^{91}$ Doris Schlechter, 'Die Geschichte der Juden in Köln', Alt Köln, 3, 10 (Aug. 1949), pp. 41-2;

'Am Dude Jüd', Jung-Köln, 1 (1952/53), pp. 1-9; 'Das Judentum in Köln', Kölnische Rundschau (9 July 1950).

${ }^{92}$ Barbara Becker-Jákli (ed.), 'Ich habe Köln doch so geliebt': Lebensgeschichten jüdischer Kölnerinnen und Kölner (Cologne, 1993).

${ }^{93}$ Wilhelm Unger, 'Un sin d'r Dom su vör mir ston', in Horst Mazerath (ed.), '... vergessen kann man die Zeit nicht, das ist nicht möglich ...' (Cologne, 1985), pp. 219-21.

${ }^{94}$ Zieher, 'Im Schatten von Antisemitismus', in Dülffer (ed.), Köln, pp. 288-9.

${ }^{95}$ On the centrality of violence to the Volksgemeinschaft idea see Richard Bessel, 'Eine "Volksgemeinschaft" der Gewalt', in Schmiechen-Ackermann (ed.), Volksgemeinschaft, pp. 357-60.

96 Thießen, 'Erinnerungen', in Schmiechen-Ackermann, Volksgemeinschaft, pp. 319-34.

${ }^{97}$ On incomplete cultural demobilization after 1918 see John Horne, 'Kulturelle Demobilmachung 1919-1939: ein sinnvoller historischer Begriff?', in Wolfgang Hardtwig (ed.), Politische Kulturgeschichte der Zwischenkriegszeit 1918-1938 (Göttingen, 2005), pp. 129-50. 
${ }^{98}$ Beatrix Hochstein, Die Ideologie des Überlebens: zur Geschichte der politischen Apathie in Deutschland (Frankfurt, 1984); Axel Schildt, Moderne Zeiten: Freizeit, Massenmedien und 'Zeitgeist' in der Bundesrepublik der 50er Jahre (Hamburg, 1995).

${ }^{99}$ Joseph Klersch, 'Volkstum und Volkstumspflege', in Joseph Klersch (ed.), Heimatchronik des Landkreises Köln (Cologne, 1954), p. 82; Joseph Klersch, 'Volkstumspflege und Volkskunde', in Joseph Klersch (ed.), Volkstumspflege und Volkskunde (Cologne, 1952), pp. 12-3.

${ }^{100}$ Joseph Klersch, 'Volk und Heimat', Unser Köln, 5/6 (1952), pp. 33-5; Joseph Klersch, Die Aufgaben der Heimat- und Volkstumspflege in der Gegenwart (Neuss, 1953), pp. 8-12; Klersch, Volkstum, p. 28.

${ }^{101}$ Max-Leo Schwering, 'Sinn und Aufgabe großstädtischer Volkstumspflege', Unser Köln, 3 (Mar. 1956), pp. 2-4.

${ }^{102}$ On massification in anti-democratic discourses see René König, 'Masse und Vermassung', in Soziologische Orientierungen: Vorträge und Aufsätze (Cologne, 1965), pp. 479-93.

${ }^{103}$ James Brophy, Popular Culture and the Public Sphere in the Rhineland, 1800-1850

(Cambridge, 2007); Reinhold Billstein (ed.), Das andere Köln: demokratische Traditionen seit der Französischen Revolution (Cologne, 1979).

104 'Kölns demokratische Verfassung 1396', Rheinische Zeitung (14 Sept. 1946); 'Bericht über die erste Tagung der Rheinischen Mundartdichtern', in Josef Lenzen and Joseph Klersch (eds), Die Rheinische Mundartdichtung (Cologne, 1949), p. 24.

${ }^{105}$ Quotation in Hans Vogts, 'Zum Geleit', in Johann Hässlin (ed.), Wanderungen durch das alte Köln (Cologne, 1955), pp. 5-6, here 6. See also Joseph Klersch, 'Kölnische Demokratie', twopart article, Alt-Köln, 1, 1 (Aug. 1947), pp. 2-3; 1, 2 (Sept. 1947), p. 3; 'Die Verfassung und Verwaltung der Stadt Köln’, Jung-Köln, special issue, 1 (Cologne, 1950), pp. 51-6; ‘Kölns Kampf um die Freiheit', Unser Köln, Sondernummer zum Altermarktspiel, 1950; 'Niedergang und Auferstehung einer Stadt', Jung-Köln, 4 (1949/50), p. 122; 'Kölnisches Wesen in Architektur geprägt', in Theo Burauen, Theo Burauen, Oberbürgermeister der Stadt Köln 19561973: Ausgewählte Ansprachen, ed. Peter Fuchs (Cologne, 1986), p. 216; 'Der Gürzenich', Unser Köln, 6 (1955), pp. 1-13. 
${ }^{106}$ On anti-Prussianism in prewar Cologne, see Stefan Lewejohann (ed.) Achtung Preußen! Beziehungsstatus kompliziert (Mainz, 2015).

107 'Die ersten Stadtvertreter von Köln eingeführt', in Peter Hasenberg (ed.), Quellen zur Geschichte Kölns in Neuester Zeit, 1945-1960 (Cologne, 1960), pp. 14-15.

${ }^{108}$ See, for example, Florian, Köln, 121.

109 Jeremy DeWaal, 'The Reinvention of Tradition: Form, Meaning and Local Identity in Modern Cologne Carnival', Central European History, 46 (2013), pp. 495-532.

${ }^{110}$ Heinrich Lützeler, Philosophie der Kölner Humors (Bonn, 1954).

${ }^{111}$ Heinrich Böll, 'Was ist kölnisch?’ in Heinrich Böll (ed.), Köln (Hamburg, 1960), p. 3; MaxLeo Schwering, 'Köln—ein Wegbereiter sozialen Fortschritts', Jung-Köln, 1 (1951/52), pp. 514.

${ }^{112}$ Joseph Klersch, Die kölnische Fastnacht von ihren Anfängen bis zur Gegenwart (Cologne, 1961), pp.175-85.

${ }^{113}$ On generalist narratives of Cologne democracy from Cologne mayors of the CDU and SPD, see "Köln, Stadt der demokratischen Freiheit: Oberbürgermeister Dr. Schwering sprach über das Fest der Rheinmetropole,” Kölnische Rundschau, June 7, 1950; ; ‘Kölnisches Wesen in Architektur geprägt', in Burauen (ed.), Fuchs (ed.), p. 216; Tilmann Pünder, 'Hermann Pünder und seine Kölner Zeit', Jahrbuch des Kölnischen Geschichtsverein 59 (1988): pp.249-294, here 264-5.

${ }^{114}$ Konrad Adenauer, 'Grundsatzrede' (1946), in Hans-Peter Schwarz (ed.), Konrad Adenauer: Reden 1917-1967 (Stuttgart, 1975), p. 82.

${ }^{115}$ For the vote returns broken down by district, see Jürgen Falter, et al., Wahlen und Abstimmungen in der Weimarer Republik: Materialien zum Wahlverhalten 1919-1933 (Munich, 1986), pp.73-5. 
${ }^{116}$ Böll did occasionally reference the low support for the Nazis at the polls; see Heinrich Böll, 'Die Preußen und wir am Rhein', in Heinrich Böll, Werke, Kölner Ausgabe, 1, ed. J. H. Reid (Cologne, 2004), pp. 139; Heinrich Böll, 'Köln eine Stadt—nebenbei eine Großstadt', in Heinrich Böll, Werke, Kölner Ausgabe, 7, ed. Ralf Schnell (Cologne, 2006), pp. 87-9. ${ }^{117}$ Paul Wolfsohn, 'Tragik in Kölns Geschichte', Alt Köln, 1, 4 (Nov. 1947), pp. 1-2. ${ }^{118}$ Eric Storm and Joost Augusteijn (eds), Region and State in Nineteenth-Century Europe: Nation-Building, Regional Identities and Separatism (Basingstoke, 2012).

${ }^{119}$ Joseph Klersch, 'Die geistigen Grundlagen der Revolution von 1848 und ihre Auswirkungen auf Köln’, Unser Köln, 4 (Oct. 1948), pp. 4-5; part 2: Unser Köln, 5/6 (Nov./Dec. 1948), pp. 1213.

${ }^{120}$ Klersch, Volkstum, p. 28.

${ }^{121}$ Karl Arnold, 'Heimat, Volkstum und Staat', Rheinischer Verein für Denkmalpflege und Heimatschütz: Mitteilungsblatt, 2 (1953), pp. 2-3.

${ }^{122}$ Max-Leo Schwering, 'Handwerk und Demokratie', Kölner Almanach, (1959-1960), pp. 3518; 'Wie würde unsere Stadt früher regiert', Jung-Köln, 3 (1961), pp. 2-6; Werner Holbeck, 'Freiheitsrechte in Köln', Jahrbuch des Kölnischen Geschichtsvereins, 41 (1967), pp. 31-95; Peter Fröhlich, Kölle noh '45 (Cologne, 1972), p. 48.

123 'Die Wacht am Rhein', Westdeutscher Beobachter (22 Nov. 1944).

124 'Kölner Kulturwoche: Europa als geistige Einheit', Kölnische Rundschau (22 Oct. 1946);

Wilhelm Steinforth, 'Einleitende Ansprache', Hermann Pünder, 'Vorwort' and

'Begrüßungsansprache', in Der Rhein und Europa: Kölner Kulturtage (Cologne, 1947), pp. 7-9, 13-14, 93-5.

${ }^{125}$ Statistisches Amt der Stadt Köln, Verwaltung sbericht, 1945/47, p. 50.

126 'Köln-eine tote Stadt?’, Unser Köln, 1 (July 1948), pp. 1-2.

${ }^{127}$ Jürgen Brügger, 'Das Kölner Domjubiläum 1948', in Dülffer (ed.), Köln, pp. 219-23.

${ }^{128}$ Jost Dülffer and Jutta Cohausz, 'Kölner für Europa', and Jürgen Mittag, 'Integration durch Kommunikation', in 'Der kölsche Europäer': Friedrich Carl von Oppenheim und die europäische Einigung (Münster, 2005) pp. 68-79, 189-200. 
${ }^{129}$ Christian Bailey, Between Yesterday and Tomorrow: German Visions of Europe, 1926-1950 (New York, 2013), pp. 172-97; On the case of the Hanseatic cities, see DeWaal, Redemptive Geographies, 90-141.

${ }^{130}$ Yuliya Komska, The Icon Curtain: The Cold War's Quiet Border (Chicago, 2015).

${ }^{131}$ Arnold, 'Heimat', pp. 2-3.

${ }^{132}$ Bailey, Between Yesterday and Tomorrow.

${ }^{133}$ Hans Peters, 'Im Geiste des Abendlandes', Kölner Almanach (1962/63), pp. 88-92.

${ }^{134}$ Adam Wrede, 'Um die Erhaltung Kölner Eigenart', Alt-Köln, 2, 3 (Mar. 1948), pp. 9-10.

${ }^{135}$ Joseph Klersch, Köln und Europa (Cologne, 1951), pp. 6, 18; Klersch, Volkstum, pp. 47-8; Joseph Klersch, 'Aufgaben und Möglichkeiten der Rheinischen Mundartdichtung', in Lenzen und Klersch (eds), Rheinische Mundartdichtung, p. 20; Joseph Klersch, 'Volk und Heimat', Unser Köln, 5/6 (1952), pp. 33-5; Klersch, Aufgaben, p. 9.

136 'Mer loße nit vum Fasteleer', Rheinische Zeitung (24 Jan. 1949).

137 'Krütz un quer durch d'r Fasteleer', Kölner Stadtanzeiger (9 Feb. 1950); 'Prinz Edmund I. regiert!', Rosenmontags-Zeitung, 1951; 'Das Regierungsprogramm', Kölner Stadtanzeiger (5 Feb. 1953).

${ }^{138}$ DeWaal, 'Reinvention'.

139 'Kölsch für Imis’, Kölnische Rundschau (11 Feb. 1954).

140 'Wieverfastelovend', Kölnische Rundschau (12 Feb. 1953).

${ }^{141}$ Carl Dietmar and Marcus Leifeld, Alaaf und Heil Hitler: Karneval im Dritten Reich (Munich, 2010), 202-8.

142 'Heimat', Alt-Köln, 4, 11 (July 1950), p. 81.

${ }^{143}$ Karl Arnold, 'Heimat und Jugend', Alt-Köln, 8, 9 (Sept. 1954), p. 33.

144 'Kölns eingeborenen bleiben klar in der Mehrheit', Kölnische Rundschau (29 Jan. 1956). ${ }^{145}$ Adolf Flecken, Gestaltung der Heimat nach rheinischer Eigenart (Neuss, 1966), pp. 15-16. 146 Theo Burauen, 'Köln und die Welt', Kölner Almanach (1961/62), p. 15; Konrad Adenauer, 'Vorwort', Kölner Almanach (1961/62), p. 8; Kölsche Toleranz stimmt immer versöhnlich', Kölnische Rundschau (26 Feb. 1960); 'Karneval zu vornehm', Kölnische Rundschau (28 Jan. 1961). 
147 'Alte Heimat-Neue Heimat', Jung-Köln, 2 (1960), pp. 1-4. For examples of the article series ‘Ausländer in Köln', see Jung-Köln, 1 (1963), pp. 18-19.

${ }^{148}$ Wolfgang Schulze-Olden, ‘Ausländische Studenten in Köln’, Kölner Almanach (1963/64), pp. 55-8.

${ }^{149}$ AG Arsch huh (ed.), Arsch huh, Zäng ussenander! Gegen Rassismus und Neonazis (Cologne, 1992). 